STUDY ON EXCLUSIVE AND ELITIST CIVICS LEARNING

\title{
KAJIAN TENTANG PEMBELAJARAN PENDIDIKAN KEWARGANEGA- RAAN YANG BERSIFAT EKSKLUSIF DAN ELITIS
}

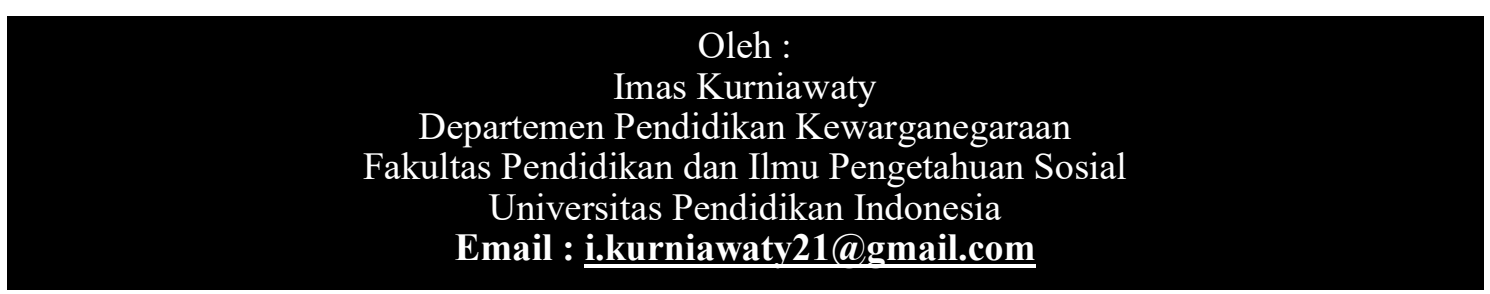

Abstract. Based on research studies conducted by David Kerr in April 1999 in the international study conducted by the "School Curriculum and Assessment Authority (SCAA)" through the "National Foundation for Educational Research in England and Wales (NFER)" with a duty to hold "international review of curriculum and assessment framework" in 16 countries around the world. From these studies, civics has some traits maximum and minimum. Civics at the minimum point marked one containing civics lesson, exclusivist and elitist emerged in the process of learning in Asian countries, including Indonesia. The purpose of study is to find out information on trends in the civics learning SMA Negeri 1 Ciwidey, which is exclusive and elitist. Be it in terms of teachers, students and schools, including several contributing factors that should be developed continuously contained in the school environtment. The method used is the case study method, which aims to reveal an intensive, detailed and in-depth evaluation of a particular symptom. Results of the study revealed that learning civics in SMA Negeri 1 Ciwidey exclusive and elitist. This is caused by the lack of school facilities and civics teacher initiatives as well as the lack of student participation in the learning process.

\section{Keywords: Exclusive and Elitist, Civics Learning}

Berdasarkan penelitian yang dilakukan oleh David Kerr pada April 1999 atas nama Otoritas Kurikulum dan Evaluasi Sekolah (SCAA) melalui Badan Nasional Penelitian Pendidikan (NFER) di Inggris, yang bertujuan untuk mereviu kerangka kurikulum dan evaluasi di 16 negara di dunia. Hasil penelitian mengungkap bahwa terdapat karakter maksimum dan karakter minimum dalam pendidikan kewarganegaraan. Pendidikan kewarganegaraan dengan karakter minimum mengandung materi kewarganegaraan dan bersifat eksklusif dan elitis, sebagaimana yang muncul dalam proses pembelajaran pendidikan kewarganegaraan di negara-negara Asia termasuk Indonesia. Penelitian ini bertujuan untuk mengetahui informasi trend pendidikan kewarganegaraan di SMA Negeri 1 Ciwidey, yang bersifat eksklusif dan elitis. Faktor-faktor yang berkontribusi terhadap pendidikan kewarganegaraan yang bersifat eksklusif dan elitis ini antara lain guru, siswa, dan lingkungan sekolah, yang harus dibangun secara terus menerus. Penelitian ini menggunakan metode studi kasus, yang bertujuan untuk mengungkap secara intensif dan mendalam dari suatu gejala tertentu. Hasil penelitian ini mengungkap bahwa pendidikan kewarganegaraan di SMA 1 Ciwidey bersifat eksklusif dan elitis. Hal ini disebabkan oleh kurangnya fasilitias sekolah dan inisiatif guru serta kurangnya partisipasi siswa dalam proses pembelajaran.

\section{Kata kunci: Ekslusif dan Elitis, Pendidikan Kewarganegaraan}

\section{A. PENDAHULUAN}

Dalam perkembangan pendidikan saat ini, pembelajaran PKn dengan berbagai metode, strategi, dan kegiatan dalam pengintegrasian budi pekerti se- dang dikembangkan. Hal ini berdasarkan penelitian riset yang dilakukan oleh David Kerr pada April tahun 1999 di 16 negara di dunia. Dari penelitian tersebut, PKn mempunyai beberapa ciri maksimal

98 Kajian Tentang Pembelajaran Pendidikan Kewarganegaraan yang Bersifat Eksklusif dan Elitis 
dan minimal. Terdapat dua ciri minimal yang terdapat di Indonesia diantaranya PKn bersifat eksklusif, artinya pembelajaran PKn cenderung tidak melibatkan atau menyambungkan ke mata pelajaran lain seperti ekonomi, sejarah, geografi dan ilmu-ilmu lainnya yang tentunya terdapat kaitannya dengan mata pelajaran PKn. Intinya PKn tidak mengglobal dan tidak berkaitan satu sama lain dengan ilmu-ilmu lainnya. Ciri kedua ialah PKn bersifat elitis, artinya dalam proses pembelajaran PKn, guru sangat mendominasi kelas dengan kata lain tidak adanya proses timbal balik (feed back) antara guru dan siswa dalam penyampaian materi di dalam kelas sehingga siswa merasa jenuh dan pembelajaran pun dirasakan monoton.

Ciri minimal ini tentunya dapat mempengaruhi berkembangnya pendidikan di Indonesia saat ini khususnya dalam mata pelajaran PKn di kancah persekolahan. Hal ini justru memicu kita untuk mengkaji lebih dalam beberapa masalah yang dihadapi oleh komponenkomponen utama dalam proses pembelajaran khususnya guru. Intinya dalam karya tulis ini penyusun akan menjelaskan hasil riset tentang proses belajar mengajar PKn, termasuk beberapa faktor pendukung yang seharusnya dikembangkan secara kontinyu (terus-menerus) yang terdapat di lingkungan sekolah.

\section{Rumusan Masalah}

Berdasarkan latar belakang diatas maka permasalahan dalam penelitian ini yaitu:

1. Bagaimana cara guru menyusun dan mengembangkan kompetensi mata pelajaran Pendidikan Kewarganegaraan ke dalam Silabus dan Rencana Pelaksanaan Pembelajaran?

2. Bagaimana guru mengimplementasikan Silabus dan Rencana Pelaksanaan Pembelajaran tersebut dalam proses pembelajaran di kelas?

3. Bagaimana cara guru menciptakan suasana kelas dan partisipasi siswa dalam proses pembelajaran $\mathrm{PKn}$ ?

4. Bagaimana kendala-kendala yang dihadapi guru sehingga pembelajaran PKn bersifat eksklusif dan elitis?

5. Bagaimana upaya guru dalam mengatasi kendala-kendala dalam pembelajaran PKn yang bersifat $e k$ sklusif dan elitis?

Sejauhmanakah upaya sekolah agar program PKn menjadi program sekolah baik di integrasikan dengan mata-mata pelajaran yang relevan maupun usaha penciptaan sekolah yang menunjang pendidikan?

\section{Metode}

Penelitian menggunakan metode deskriptif, yaitu metode yang akan 
menghasilkan laporan penelitian yang berisi kutipan-kutipan data (berupa katakata, gambar dan bukan angka-angka) untuk memberi gambaran penyajian laporan tersebut" (Moleong, 2004:10). Sedangkan bentuk penelitiannya adalah studi kasus, Hal ini seperti diungkapkan oleh Arikunto (1996:129-130) bahwa "penelitian kasus adalah penelitian yang dilakukan secara intensif, terinci dan mendalam terhadap suatu organisasi, lembaga atau gejala tertentu". Ditinjau dari wilayahnya, maka penelitian kasus hanya meliputi daerah atau subjek yang sangat sempit. Tetapi ditinjau dari sifat penelitian, penelitian kasus lebih mendalam.

Penulis menggunakan empat instrumen pengumpul data, yaitu observasi, wawancara, studi dokumentasi dan studi literatur. Observasi dilakukan selama penelitian berlangsung dengan tujuan mengetahui situasi dan kondisi serta kebiasaan-kebiasaan yang terjadi, pengamatan berkenaan dengan proses kegiatan belajar mengajar PKn yang cenderung bersifat eksklusif dan elitis. Wawancara dilakukan kepada guru mata pelajaran PKn, guru mata pelajaran lain (yang dapat menunjang pada fokus penelitian), dan siswa. Dalam studi dokumentasi, peneliti memeroleh data mengenai standar isi PKn, silabus beserta RPP
(Rencana Persiapan Pengajaran), dokumen-dokumen tes selama melakukan ujian kepada peserta didik, profil sekolah, serta data-data sekolah. Sedangkan studi literatur, peneliti mencari data berupa teori-teori, pengertianpengertian dan uraian-uraian yang dikemukakan oleh para ahli sebagai landasan teoritis, khususnya mengenai masalah-masalah yang sejalan dengan penelitian ini.

\section{B. HASIL DAN PEMBAHASAN}

Teknik penelitian observasi dilakukan untuk meninjau keadaan yang sebenarnya di sekolah mengenai pembelajaran Pendidikan Kewarganegaraan yang bersifat Eksklusif dan Elitis di SMA Negeri 1 Ciwidey. Pada pembelajaran PKn ini terdapat beberapa kelemahan dan kelebihan yang dapat mempengaruhi berhasil atau tidaknya sebuah pembelajaran. Pada pembelajaran PKn ini, diawali oleh dapat menyampaikan dengan banyak metode dan tentunya ditunjang oleh beberapa media. Selain itu juga, guru juga harus memiliki teknik-teknik khusus dalam menyampaikan pembelajaran pada saat kegiatan belajar mengajar di kelas. Metodemetode yang ada belum tentu berjalan dengan lancar tanpa adanya media, teknik, serta pengelolaan kelas yang baik dari pihak sekolah. 
Adapun hasil observasi dan dokumentasi yang dilakukan oleh penulis diperoleh data sebagai berikut:

\section{Pengembangan Standar Isi Pen- didikan Kewarganegaraan SMA ke dalam Silabus dan Rencana Pelaksanaan Pembelajaran (RPP)}

Dalam standar isi pembelajaran PKn di SMA Negeri 1 Ciwidey dikembangkan ke dalam Silabus dan Rencana Pelaksanaan Pembelajaran (RPP). Untuk kelas X, XI IPS dan XI IPA, standar isi PKn dikembangkan ke dalam silabus dan RPP dengan mengacu pada kurikulum Tahun 2006 yaitu Kurikulum Tingkat Satuan Pendidikan (KTSP). Sedangkan kelas XII IPS dan XII IPA, standar isi PKn dikembangkan ke dalam silabus dan RPP dengan mengacu pada kurikulum Tahun 2004 yaitu Kurikulum Berbasis Kompetensi (KBK). hal pengalokasian waktu pertemuan pembelajaran PKn di SMA Negeri 1 Ciwidey dalam setiap satu jam pelajarannya dialokasikan selama 45 menit. Untuk kelas X, pembelajaran PKn hanya dilakukan pada satu kali pertemuan dalam satu minggu dengan alokasi waktu 45 menit. Untuk kelas XI IPS dan IPA durasi pertemuan perminggu $2 \mathrm{x}$ 45 menit. Sedangkan untuk kelas XII IPA durasi 2 x 45 menit pertemuan perminggunya, khusus untuk kelas XII IPS pertemuan pembelajaran PKn perminggunya $3 \times 45$ menit. pemilihan metode pembelajaran PKn terlihat lebih menonjol pada metode yang mengutamakan aspek kognitif (civic knowledge) siswa. Namun dalam proses penilaian, guru mata pelajaran PKn memadukan ketiga aspek yaitu aspek afektif, aspek kognitif dan aspek psikomotor. Dan penilaian di akhir pembelajaran, guru mata pelajaran PKn lebih mengutamakan penilaian dari aspek afektif. guru mata pelajaran menggunakan metode ceramah bervariasi, diskusi, mengkaji buku sumber yang dikaitkan dengan isu-isu kontroversial yang sedang mengglobal akhir-akhir ini, tanya jawab dan presentasi. Dalam silabus dan RPP juga dapat dilihat bahwa alat dan sumber belajar yang digunakan masih mengandalkan buku sumber dan media massa dan elektronik. Sedangkan dalam hal evaluasi yang direncanakan dalam silabus dan RPP masih berorientasi pada proses dan hasil. Pada pemilihan jenis evaluasi, guru tidak hanya terbatas pada tertulis saja namun pada tes lisan dan performance test (baik individu maupun kelompok), dan dalam pelaksanaan tes tertulis, guru mata pelajaran menyesuaikan pada kompetensi dasar pada silabus di setiap materi bahasan. Pada intinya, secara keseluruhan memang terlihat jelas bahwa pembelajaran PKn yang di- 
tuangkan dalam silabus dan RPP masih cenderung bersifat eksklusif.

\section{Implementasikan Silabus dan Rencana Pelaksanaan Pembelaja- ran dalam Proses Pembelajaran Pendidikan Kewarganegaraan di Kelas}

Dalam hal pengimplementasian pengembangan silabus dan RPP, guru mengalami ketidaksesuaian antara waktu pengembangan kompetensi dasar ke dalam silabus dan RPP dengan waktu pelaksanaan silabus dan RPP pada saat proses pembelajaran di kelas. Seringnya guru alami kemelesetan rencana-rencana awal di silabus dan RPP serta dalam menyesuaikan bobot materi dengan pengalokasian waktu. Pada pelaksanaannya guru mengawalinya dengan Apersepsi dan set induction seperti mengondisikan siswa agar kondusif untuk belajar, menyesuaikan dengan agenda kelas supaya guru dapat mengetahui kehadiran siswa. Lalu setelah itu barulah guru memulai pada kegiatan inti, menjelaskan materi yang dibahas dengan menggunakan metode-metode yang sesuai, seperti metode ceramah bervariasi dan metode diskusi. Hanya saja dengan menggunakan metode diskusi guru selalu kewalahan dalam penyesuaian penyampaian materi dengan pengalokasian waktu. Hal ini terungkap pada saat penelitian di sekolah, peneliti menemukan kasus yaitu dalam proses pembelajaran di kelas akan menggunakan metode diskusi yang membahas tentang pokok bahasan yang akan dibahas, namun karena alokasi waktu yang tidak mencukupi maka diskusi kelompok tersebut tidak selesai dan menggantung pada kesimpulan yang belum pasti dan kurang dimengerti oleh siswa itu sendiri. Memang guru juga tidak dapat dipersalahkan dalam hal ini, karena dilihat oleh peneliti siswa banyak yang acuh tak acuh pada saat diskusi berlangsung. Dalam hal metode diskusi, guru hanya bertindak menjadi fasilitator atau hanya sekedar sebagai pengamat jalannya diskusi saja. Penyebab kurangnya alokasi waktu yang digunakan terpakai oleh pembahasan tugas-tugas rumah dan pembahasan Lembar Kerja Siswa (LKS).

3. Penciptakan Suasana Kelas dan Partisipasi Siswa dalam Proses Pembelajaran Pendidikan Kewarganegaraan

Penciptaan suasana kelas dan sekolah serta partisipasi atau keaktifan siswa dalam proses pembelajaran di kelas secara keseluruhan masih bersifat elitis. Hal tersebut disebabkan karena pada setting kelas, sekolah memang tidak dilakukan adanya moving class baik itu masalah perubahan bangku kelas dan 
alat pelengkap belajar mengajar. Posisi setting kelas tersebut masih tetap bersifat elitis. Dimana posisi bangku tetap baku, kaku dan tradisional serta terkadang siswa merasa tegang. Hal ini disebabkan karena metode yang digunakan metode ceramah bervariasi yang dikombinasikan dengan metode tanya jawab pada saat kegiatan belajar berlangsung sehingga membuat siswa memperhatikan dengan seksama guru yang sedang mengajar. Partisipasi siswa di waktu kegiatan belajar mengajar dirasakan kurang di kelas pada saat pembelajaran PKn.

\section{Kendala-kendala yang Dihadapi Guru sehingga Pembelajaran Pen- didikan Kewarganegaraan Bersi- fat Eksklusif dan Elitis}

Seiringnya dengan adanya pergantian kurikulum maka berubah pula komponen-komponennya mulai dari format silabus dan RPP hingga materi yang diajarkan kepada siswa, selain itu juga dalam membuat RPP, guru harus memperhatikan kondisi lingkungan belajar siswa, karakteristik siswa, potensi guru, metode dan media belajar sehingga dapat menarik perhatian siswa. Akan tetapi dalam pelaksanaannya, guru sering mengalami kendala dari segi pembuatan serta pelaksanaan RPP yang sudah dirancang sedemikian rupa sering kali berubah dan meleset dari perkiraan, hal ini disebab- kan karena kondisi siswa berbeda disetiap kelasnya. Selain itu pula, guru mengalami kendala dalam hal pembagian waktu/alokasi waktu dalam pembelajaran PKn. Waktu pembelajaran yang singkat, sehingga membuat guru kesulitan dalam mengejar materi sesuai target silabus. Kendala lainnya, yaitu perihal sarana dan prasarana dalam pembelajaran PKn di sekolah. Dalam pembelajaran PKn tentunya belum lengkap apabila tanpa adanya fasilitas sumber/bahan belajar seperti buku-buku paket PKn, labilnya motivasi siswa dalam pembelajaran PKn dan tentunya ruangan laboratorium demokrasi.

\section{Upaya Guru dalam Mengatasi Ken-} dala-kendala dalam Pembelajaran Pendidikan Kewarganegaraan yang Bersifat Eksklusif dan Elitis

Dalam mengatasi kendala-kendala tersebut, guru PKn dalam hal pengalokasian waktu baiknya lebih memerhatikan dan menyesuaikan dengan indikator yang dicapai, guru mampu mengelola kelas dengan baik sehingga kelas menjadi hidup, demokratis dan interaktif serta terciptanya komunikasi antara guru dan siswa, siswa dan siswa lainnya. Guru juga harus mencari cara dalam memerjelas bahan ajar, yaitu dengan cara guru memfokuskan diri pada bahan ajar yang akan diajarkan di kelas supaya tujuan 
pembelajaran dapat tercapai sesuai target silabus dan RPP. Sedangkan dalam upaya untuk mengatasi keterbatasan sarana dan prasarana, guru harus lebih aktif dan kreatif dalam mencari sumber atau media belajar. Selain itu pula, guru mata pelajaran PKn juga mengikuti berbagai seminar, pelatihan dari Dinas Pendidikan dan LPTK, In House Training (IHT), serta melakukan dialog-dialog atau sharing secara personal dengan Guru PKn lainnya, dan guru PKn melakukan Sharing secara formal dengan pakar/praktisi PKn mengenai berbagai kendala/masalah yang dihadapi dalam pembelajaran PKn, guru mata pelajaran pun melakukan diskusi pada saat Musyawarah Guru Mata Pelajaran (MGMP).

6. Upaya Sekolah agar Program Pendidikan Kewarganegaraan menjadi Program Sekolah Baik di Integrasikan dengan Mata-mata Pelajaran yang Relevan maupun Usaha Penciptaan Sekolah yang Menunjang Pendidikan

Upaya sekolah dalam hal pengintegrasian mata pelajaran PKn dengan mata pelajaran lain yaitu dengan cara membuat sosialisasi antar guru mata pelajaran, agar dapat memberi andil dan tanggung jawab yang besar terhadap pembinaan watak, ketaqwaan dan budi pekerti yang luhur siswa di sekolah. Selain itu juga, sekolah mengadakan outbond atau study tour/studi banding ke museum, gedung DPRD atau pun ke tempat-tempat yang ada hubungannya dengan materi pada mata pelajaran. Namun hal ini masih kurang dijalankan dan diterapkan dengan baik, karena keterbatasan fasilitas dan upaya sekolah dalam menjalankan program PKn ini di dalam program sekolah. Terkait dengan program PKn ini, sekolah masih belum mendirikan untuk membuat ruangan khusus bagi mata pelajaran PKn yaitu Laboratorium Demokrasi.

Berdasarkan hasil penelitian maka dapat diketahui beberapa temuan yaitu guru mengalami beberapa kesulitan terutama dalam proses pengembangan kompetensi dasar yang harus dicapai oleh siswa, sehingga guru harus paham dan menguasai langkah-langkah dalam pengembangan silabus dan rencana pelaksanaan pembelajaran. Dalam proses pembelajaran, keberadaan Perangkat silabus dan Rencana Pelaksanaan Pembelajaran sangat diperlukan. Guna terorganisirnya pelaksanaan pembelajaran di sekolah. Tanpa adanya perangkat pembelajaran ini, guru akan alami kesulitan dalam menyampaikan materi di kelas. Pengembangan kompetensi dasar ini dituangkan dalam perangkat silabus dan dikembangkan lebih detail lagi pada Rencana Pelaksanaan Pembelajaran 
(RPP). Silabus merupakan penjabaran standar kompetensi dan kompetensi dasar ke dalam materi pokok/pembelajaran, kegiatan pembelajaran, dan indikator pencapaian kompetensi untuk penilaian. Terdapat beberapa prinsip dalam mengembangan silabus, yaitu: ilmiah, relevan, sistematis, konsisten, memadai, aktual dan kontekstual, fleksibel dan menyeluruh (BSNP, 2006: 14-15). Aspekaspek kompetensi yang hendak dikembangkan dalam pembelajaran pendidikan kewarganegaraan dalam silabus dan RPP adalah Aspek-aspek yang mencakup pengetahuan kewarganegaraan (civic knowledge); keterampilan kewarganegaraan (civic skills) dan watak atau karakter kewarganegaraan (civic dispositions). Dalam Standar Isi Pendidikan Nasional tahun 2006 antara lain dijelaskan pula bahwa kelompok mata pelajaran kewarganegaraan dan kepribadian dimaksudkan untuk meningkatan kesadaran dan wawasan peserta didik akan status, hak, dan kewajibannya dalam kehidupan bermasyarakat, berbangsa, dan bernegara, serta peningkatan kualitas dirinya sebagai manusia.

Pada saat pelaksanaan dari pengembangan kompetensi dasar ke dalam silabus dan rencana pelaksanaaan pembelajaran, guru sering alami kemelesetan rencana awal. Sewaktu pembelajaran berlangsung rencana awal bisa saja berubah. Terutama hal-hal yang berkaitan dengan pengalokasian waktu. Oleh karena itu, guru sebisa mungkin merancang pula perencanaan yang tak terduga guna untuk menanggulangi hal-hal yang berubah pada saat proses kegiatan belajar. Terbayang jika guru tidak merencanakan dahulu dengan menggunakan silabus dan RPP. Silabus dan RPP dirancang dan dibuat sesuai kurikulum yang berlaku sebagai bahan pedoman guru dalam melaksanakan proses kegiatan belajar. Dalam silabus dan RPP mata pelajaran Pendidikan Kewarganegaraan (PKn), harus terdapat target pencapaian pada siswa sesuai yang termaktub dalam visi, misi, dan tujuan mata pelajaran PKn.

PKn atau Civic Education adalah program pendidikan/pembelajaran yang secara programatik - prosedural berupaya memanusiakan (humanizing) dan membudayakan (civilizing) serta memberdayakan (empowering) manusia/anak didik (diri dan kehidupannya) menjadi warga negara yang baik sebagaimana tuntutan keharusan/yuridis konstitusional bangsa/negara ybs. (Djahiri, 2006:9). Menurut Prof. Drs. H.A. Kosasih Djahiri, terdapat tantangan dan keputusan yang harus ditetapkan guru minimal pada momentum sbb:

a. Saat melakukan kaji telik (analisis) the intended program, menentukan 
kelayakan dan atau kekurangan dll;

b. Saat melakukan evaluasi/diagnosa peserta didik dan lingkungan belajarnya serta dunia the hidden lainnya, harus menentukan kelayakan penyesuaian dll;

c. Saat RPP selesai dan siap pakai, menentukan ketepatgunaan dan kehandalannya;

d. Saat RPP dilaksanakan atau momentum pelakonan KBM, melihat dan membaca aksi-reaksi peserta didik serta suasana KBM untuk selanjutnya menentukan berbagai keputusan yang positif dan menguntungkan.

e. Saat KBM selesai dan akan menentukan alat ukur penilaian, menentukan pola, isi dan kriteria evaluasi;

f. Saat evaluasi atau pengukuran dilaksanakan dan dikaji serta diperoleh hasilnya, menentukan peringkat keberhasilan/kekurangan serta tindak lanjutnya.

Diantara momentum dari paparan diatas, yang paling esensial adalah momentum saat KBM berlangsung. Segala kepekaan dan kemahiran profesional guru diminta dikerahkan untuk "membaca peserta didik dan suasana $K B M$ ' untuk selanjutnya didiagnosa kelayakan dan keharusannya dan ditetapkan seketika tindakannya yang tepat serta mendukung kelayakan PBM selanjutnya.

Dalam penggunaan metode yang dapat memakan waktu pembelajaran, guru harus cerdik dalam menyiasatinya. Namun, seringnya guru menggunakan metode yang biasa dilakukan dan dapat secara gamblang menjelaskan materi kepada siswa yaitu metode ceramah bervariasi. Selain itu juga, guru kurang menggunakan sumber/bahan belajar yang kurang memadai dikarenakan kurangnya fasilitas sekolah. Akan tetapi terdapat kelebihan guru pada saat proses pembelajaran, dalam hal penilaian guru tidak hanya menilai dari aspek kognitif saja, tetapi dari aspek afektif dan aspek psikomotor juga.

Dalam suasana pembelajaran di kelas yang masih elitis dapat mempengaruhi partisipasi siswa pada saat pembelajaran di kelas. Menurut David Kerr (1999:26), Elitis yaitu proses pembelajaran PKn, guru sangat mendominasi kelas dengan kata lain tidak adanya proses timbal balik (feed back) antara guru dan siswa dalam penyampaian materi di dalam kelas sehingga siswa merasa jenuh dan pembelajaran pun dirasakan monoton. Sikap guru merupakan indikator dalam kegiatan belajar mengajar. Sikap guru ini termasuk sikap guru dalam memperhatikan siswa di dalam kelas maupun di luar kelas. Karena sikap guru merupakan salah satu faktor utama dalam pembelajaran di persekolahan. Karena tanpa adanya faktor ini, kegiatan pembelajaran tak lengkap dan berjalan sesuai tujuan yang diinginkan. Sesuai dengan hasil observasi, terungkap bahwa dalam penciptaan suasana sekolah cukup kondusif 
untuk dijadikan lingkungan sekolah. Tetapi, dalam setting kelas, masih baku, kaku dan tradisional. Dalam pembelajaran di kelas, posisi guru dan siswa masih tradisional dan terasa baku. Sehingga menimbulkan suatu pembelajaran yang kaku dan terjadi pendominasian guru pada saat proses pembelajaran. Perubahan setting bangku kelas terjadi hanya pada saat guru menggunakan metodemetode pembelajaran tertentu, seperti metode diskusi. Tetapi setting bangku kelas pun dirubah seperti sedia kala apabila telah selesai diskusinya. Di setiap lingkungan sekolah, tentunya warga sekolah mengharapkan lingkungan sekolah yang bersuasana kondusif. Namun hal itu harus didukung oleh banyak faktor dan dilaksanakan dan merupakan tanggung jawab bersama baik itu seluruh warga sekolah dan pihak lainnya yang terkait.

Dalam menyikapi pergantian kurikulum, guru harus mendalami karakteristik, kelebihan dan kekurangan dari kurikulum yang baru sekarang ini, sehingga dalam KBM guru dapat lebih kreatif dalam menggunakan sumber belajar sesuai dengan fasilitas yang ada. Sejak Pendidikan Kewarganegaraan (PKn) diimplementasian di Indonesia pada berbagai jenis dan jenjang pendidikan (persekolahan maupun perguruan tinggi), subjek pembelajaran tersebut menghadapi berbagai kendala dan keterbatasan. Menurut Budimansyah (2006: 38), kendala dan keterbatasan tersebut adalah:

a. Masukan instrumental (instrumental input) terutama yang berkaitan dengan kualitas guru/dosen serta keterbatasan fasilitas dan sumber belajar, dan

b. Masukan lingkungan (environtmental input) terutama yang berkaitan dengan kondisi dan situasi kehidupan politik negara yang kurang demokratis.

Dengan demikian, pelaksanaan PKn tidak mengarah pada misi yang seharusnya. Beberapa indikasi empirik yang menunjukkan salah arah tersebut antara lain adalah sebagai berikut:

Pertama, proses pembelajaran dan penilaian dalam PKn lebih menekankan pada dampak instruksional (instructional effects) yang terbatas pada penguasaan materi (content mastery) atau dengan kata lain hanya menekankan pada dimensi kognitifnya saja. Sedangkan pengembangan dimensi-dimensi lainnya (afektif dan psikomotorik) dan pemerolehan dampak pengiring (nurturant effects) sebagai "hidden curricullum" belum mendapat perhatian sebagaimana mestinya. Kedua, pengelolaan kelas belum mampu menciptakan suasana kondusif 
dan produktif untuk memberikan pengalaman belajar kepada siswa/ mahasiswa melalui perlibatannya secara proaktif dan interaktif baik dalam proses pembelajaran di kelas maupun di luar kelas (intra dan ekstra kurikuler) sehingga berakibat pada miskinnya pengalaman belajar yang bermakna (meaningful learning) untuk mengembangkan kehidupan dan perilaku siswa/mahasiswa. Ketiga, pelaksanaan kegiatan ekstrakurikuler sebagai wahana sisiopedagogis untuk mendapatkan "handson experience” juga belum memberikan kontribusi yang signifikan untuk menyeimbangkan antara penguasaan teori dan praktek pembiasaan perilaku dan keterampilan dalam berkehidupan yang demokratis dan sadar hukum (Budimansyah, 2006: 38-39).

Dari paparan diatas, maka kekurangan dan keterbatasan pendidikan saat ini ialah keterbatasan dari berbagai faktor, terutama keterbatasan dari pihak sekolah yaitu keterbatasan dalam fasilitas dan sumber belajar dalam mendukung kegiatan belajar mengajar. Dengan keterbatasan inilah, guru harus pintar-pintar mengatur siasat untuk lebih kreatif dan aktif dalam mengatasi keterbatasan dan menggunakan fasilitas yang mendukung sumber belajar dalam kegiatan belajar mengajar di kelas.
Berdasarkan temuan di lapangan, dalam proses pembelajaran guru lebih sering dalam penggunaan metode yang itu-itu saja seperti ceramah bervariasi. Hal tersebut menyebabkan pembelajaran PKn yang cenderung eksklusif dan bersifat elitis. Membuat siswa bosan, jenuh dan suasana kelas menjadi beku. Tidak menutup kemungkinan juga dapat menyebabkan kejenuhan guru dalam mengajar. Oleh karena itu, sesuai dengan temuan lapangan juga dapat di cari jalan keluar untuk semua kendala itu. Dengan menggunakan metode pilihan yang bermutu seperti dengan menggunakan dan diterapkan metode pembelajaran diskusi dan metode games di SMA Negeri 1 Ciwidey. Dengan sedikit demi sedikit dapat membuka kreatifitas, keaktifan, dan partisipasi siswa di kelas pada pembelajaran PKn. Sehingga dapat disimpulkan bahwa dalam memecahkan kendala pembelajaran PKn yang cenderung eksklusif dan elitis di SMA Negeri 1 Ciwidey, guru dapat menggunakan metode pembelajaran diskusi dan metode pembelajaran games.

Peningkatkan program PKn di sekolah harus ditunjang dengan sarana dan prasarana yang baik seperti didirikannya Laboratorium Demokrasi di sekolah. Pendidikan persekolahan seyogyanya dikembangkan sebagai wahana 
sosial kultural untuk membangun kehidupan yang demokratis. Hal ini dapat diartikan bahwa sekolah harus menjadi wahana pendidikan untuk mempersiapkan kewarganegaraan yang demokratis melalui pengembangan kecerdasan spiritual, rasional, emosional, dan sosial warganegara baik sebagai aktor sosial maupun sebagai pemimpin/khalifah pada hari ini dan hari esok. Fungsi laboratorium PKn adalah:

a. Sebagai lembaga yang membantu mengembangkan Iptek dan sains dalam pendidikan khususnya PKn

b. Sebagai wahana untuk mengadakan penelitian ilmiah dalam bidang PKn dan ilmu-ilmu sosial lainnya

c. Sebagai wahana untuk mengadakan pendidikan, latihan, dan sosialisasi, khususnya tentang hasil penelitian serta inovasi baru tentang PKn dan ilmu sosialnya.

d. Sebagai sarana untuk mengembangkan kreatifitas, inovasi mahasiswa jurusan PKn dalam kajian; ilmu politik, hukum, IKN, dan ilmu sosial lainnya dalam kontek pendidikan khususnya dan Iptek pada umumnya. (Danial, 2006: 146).

Sekolah sebagai bagian integral dari masyarakat perlu dikembangkan sebagai pusat pembudayaan dan pemberdayaan peserta didik sepanjang hayat, yang mampu memberi keteladanan, membangun kemauan, dan mengembangkan kreativitas peserta didik dalam proses pembelajaran demokratis. Dengan demikian secara bertahap sekolah akan menjadi komunitas yang memiliki budaya yang berintikan pengakuan dan penghormatan terhadap hak dan kewajiban serta keharmonisan dalam menjalani kehidupan bermasyarakat yang tertib, adil dan berkeadaban.

\section{SIMPULAN DAN SARAN}

Secara sosiografi SMA Negeri 1 Ciwidey merupakan area persekolahan yang strategis, jauh dari kebisingan kota, bebas polusi kendaraan bermotor, udara yang segar dengan view yang indah, sehingga dapat mendukung terciptanya proses pembelajaran yang kondusif dan efektif.

Pembelajaran PKn yang bersifat eksklusif dan elitis dapat ditemukan dari cara mengajar guru, baik itu dari segi penggunaan metode, setting kelas, alat peraga yang digunakan, non koordinasi dengan guru-guru bidang studi yang relevan, kurangnya pengkaitan materi dengan ilmu-ilmu lainnya, pengkaitan materi dengan isu-isu global dan kurangnya inisiatif guru terhadap kebutuhan siswa pada saat penyusunan dan pengembangan silabus dan RPP.

Penyebab dari pembelajaran yang eksklusif dan elitis ini ialah kurangnya fasilitas sekolah dan inisiatif guru PKn dalam proses pembelajaran.

Untuk mengatasi pembelajaran yang eksklusif dan elitis, guru PKn dapat 
Edutech, Tahun 16, Vol.16, No.1, Februari 2017

menggunakan metode pembelajaran diskusi dan metode pembelajaran games (permainan). Dengan penggunaan kedua metode pembelajaran tersebut, dapat berpengaruh besar terhadap suasana kelas dan kegiatan belajar mengajar PKn di kelas pun menjadi pembelajaran yang menyenangkan dan mendidik bagi siswa.

Upaya-upaya yang dilakukan oleh guru PKn dalam menghadapi masalah pembelajaran PKn yang Eksklusif dan Elitis ini diperlukan keikutsertaan guru PKn pada setiap seminar-seminar, pelatihan-pelatihan yang memberikan strategi model pembelajaran student centered, pertemuan diskusi guru bidang studi, in house training, dan diskusi-diskusi yang dapat membantu kretifitas guru PKn dalam pembelajaran PKn. Walaupun demikian karena inisiatif guru masih rendah maka kendala-kendala yang menyebabkan pembelajaran $\mathrm{PKn}$ bersifat eksklusif dan elitis masih dapat dikenali secara tertulis.

Penerapan program PKn yaitu laboratorium PKn/demokrasi di SMA Negeri 1 Ciwidey dapat meningkatkan kualitas pembelajaran dan tercapainya tujuan pembelajaran PKn.

\section{DAFTAR PUSTAKA}

Arikunto, Suharsimi. (1996). Prosedur Penelitian Suatu Pendekatan Praktek. Jakarta: PT Rineka Cip- ta.

Badan Standar Nasional Pendidikan. (2006). Panduan Penyusunan Kurikulum Tingkat Satuan Pendidikan Dasar dan Menengah. Jakarta: BSNP.

Budimansyah, Dasim \& Syaifullah Syam. (2006). Pendidikan Nilai Moral dalam Dimensi Pendidikan Kewarganegaraan (Menyambut 70 Tahun Prof. Drs. H. A. Kosasih Djahiri). Bandung: Laboratorium Pendidikan Kewarganegaraan (PKn) FPIPS-UPI.

Djahiri, Kosasih. (2006). Kapita Selekta Pembelajaran Pembaharuan Paradigma PKn-PIPS-PAI. Bandung: Laboratorium PKn UPI.

Danial, Endang, (2006), Peran Laboratorium PKn dalam Meningkatkan Kualitas Pembelajaran, Bandung Laboratorium PKn.

Departemen Pendidikan Nasional. (2003). Kurikulum 2004 SMA. Pedoman Khusus Pengembangan Silabus dan Penilaian Mata Pelajaran Kewarganegaraan. Jakarta: Depdiknas.

Kerr, David. (1999). Citizenship Education: an International Comparison. London.

Moleong, Lexy J. (2004). Metodologi Penelitian Kualitatif. Bandung: 